الاورية العلمية لكلية الفنون الجميلة - جامعة الإسكندرية

SJFA

Scientific Journal of the Faculty of Fine Arts Alexandria University

\title{
Restoration Towards Sustainable Green Heritage Buildings, Case Study: Mansoura Opera House, Mansoura, Egypt
}

\author{
Dr. Mohamed M. Shawky Abou Leila ${ }^{1}$ \\ Dr. Mai Wahba Mohamed Madkour ${ }^{2}$
}

\section{ABSTRACT}

Egypt is considered as one of the most important countries that contain many valuable heritage buildings. Most of these buildings suffer from neglect, deterioration, lack of investment and maintenance. That reflected itself on the deterioration of building`s architectural situation. These buildings lost their cultural, economic, and social significance over time. This needs the intervention of research to find solutions for restoration of buildings of historical value that enable their reuse in the appropriate context. Green architecture is a widespread trend in the last two decades. Principles of green buildings have to be considered when restoring historically valuable buildings in order to achieve sustainable green heritage areas. This research aims to accomplish heritage building's complete sustainability through the incorporation of green architecture principles into the process of restoration of historically valuable buildings. This can, of course, means meeting the needs of new generations without risking the loss of heritage buildings` value.

The methodology of this research includes; first the theoretical part that includes definitions of heritage, green buildings, policies, principles, and types of restoration projects. In its analytical part, the research presents an international model of transforming a heritage building into a green building. The applied case study then presents a number of recommendations for restoration of Mansoura opera house as one of the most significant heritage buildings in the city of study while considering green and sustainability criteria.

KEYWORDS: Restoration, heritage buildings, conservation, green heritage, sustainability, Mansoura opera house.

\section{INTRODUCTION}

\subsection{Heritage Definition}

Generally, Heritage as a concept is related to anything inherited and passed on from past to future. It is often related to traditions, believes and Achievements. It expresses the exchange of things of quality from ancestors to future generations [1].

The International Charter for Cultural Tourism defines heritage as "a broad concept referring to the natural and cultural environment. It includes the coordination of land, places, and sites and built environments as well as biodiversity, past ongoing cultural practices, knowledge and life experiences.

\footnotetext{
${ }^{I}$ Associate Professor - A.E.D., Faculty of Engineering, Mansoura University, Egypt m_shawkylila@yahoo.com, mmshlila@mans.edu.eg

${ }^{2}$ Lecturer of Architecture - A.E.D., Faculty of Engineering, Tanta University, Egypt And General Manager - EAE Program, Faculty of Engineering, Tanta University, Egypt maimadkour@yahoo.com, mai_madkour@f-eng.tanta.edu.eg
} 
Which constitute the core of the original local, national and regional identity so that it is an intertwined component of modern life [2].

\subsection{Restoration of Heritage Buildings \\ 1.2.1 International conventions, Policies for revival and reconstruction of destroyed heritage buildings dealing with heritage in general: \\ 1.2.1.1 Cultural property protection convection (1954) [3]:}

Wars, disasters, and revolutions took part in disfiguring urban architectural history of nations represented by heritage buildings and areas. Thus, calls for heritage preservation continued to satisfy the need for regulations to protect heritage. In that perspective heritage conservation convection treaty 1954 was the first of its kind. On the light of it, the United Nations organization is held responsible for protecting heritage buildings in different countries in case of war and even armed force may apply to ensure all the parties obey the treaty. Hague agreement 1954 also necessitated the protection of cultural properties in areas of armed conflicts. In the same context, it is important to emphasize that the negative impact of latest assaults in both Iraq and Lebanon are in fact violations of international agreements. The agreement has a number of articles that regulate the execution of this convection.

Articles 2, 3, 4 and 10 define protection as the safeguarding of property represented by measures taken in peace-time to counter any possible assaults on the properties in their territories. These properties are to be respected by avoiding their use together with their surroundings in any demeanor that subject them to damage. Thus, these properties are to be marked and external forces are allowed to interfere for ensuring the execution of the convection.

\subsubsection{International Charter for Conservation and Restoration of Monuments and Sites (The Charter of Venice) 1964 [4] (ICCRMS)}

This charter is of significance through which the historic buildings were considered as historic sites and through which non-intangible heritage was first comprehended. The charter revealed the importance of a broad understanding of maintenance and conservation as well as documentation of historic studies ahead of any executive process. Documentation should be conducted before and during Accompanied by figures and photographs for archiving and made available.

Articles 4-8 of the charter deal with the issue of conservation where monuments can be conserved by making them used publically without change. The function of the building might be altered under strict circumstances. Construction or demolition or any kind of modification that change color or mass are not allowed in any way. The monument is not separable from its history and place of its existence, so in case parts of the monument or the monument as a whole needed to be moved for protection, this may take place only under strict justifiable conditions. Pieces of art such as sculptures, paintings and decorations can only be removed from monuments for their preservation and safekeeping.

Articles 9-13 of the charter are mainly related to restoration and in which restoration is considered a technical process that must be proceeded with a large number of archeological and historical studies of the monument in order to maintain its value and original material. In case no data is available no guessing is allowed and it is not in any possible to give the monument any contemporary features. Traditional techniques are preferable to be used unless they were found unfit modern techniques may be used but their usefulness has to be verified by scientific data. Monument building usually is in layers that tells about the history it witnessed so the restoration is not about unity of style it's more about maintaining.it is not allowed to reveal a layer on expense of another unless the one removed is of little importance or the layer to be exposed is of much greater historical or archeological value and the decision in case of 
destruction is not for the individuals carrying out the work. In case any replacements are required, that has to be in harmony with the whole and indistinguishable from original parts.

\subsubsection{Types of restoration projects}

There are several types of restoration projects that include; partial restoration projects, comprehensive restoration projects, periodic maintenance projects and projects of rehabilitation and coordination of heritage building surroundings.

- Partial Restoration Projects (PRP): are specific and they are concerned with finding scientific and engineering solutions to deal with current or expected damages or to provide new solutions for heritage complementary works.

- Comprehensive Restoration Project (CRP): on the other hands includes studies of more than one restoration field, it requires the participation of specialists in the areas required to work as an integrated team, as well as the project of deconstruction and reconstruction, which may be partial or holistic and is concerned with the dismantling of one or more architectural elements as an irreplaceable alternative solution.

- Periodic Maintenance and Cleanliness Projects (PM\&CP): these are more related to heritage buildings that are intact.

- Rehabilitation and Coordination of the Site Surrounding Heritage Building Projects (R\&CSSHB): that includes; streets, squares, green spaces and adjacent buildings, in order to achieve visual and elemental coherence and that also extend to complementary landscape like parking lots, sidewalks and green areas [5].

The restoration project should include a series of studies, tests and measurements covering all the following aspects: historic and cultural studies, the architecture of the current situation, solutions and suggested procedures

\subsubsection{Most important principles of the restoration process:}

The scientific theory of restoration, which was expressed by the Italian Charter of Restoration in 1972, included some items such as allowing only the minor complementary works indispensable to the safety of the heritage building, preserving all periods of construction of the heritage building, avoiding disfiguring additions Replacing the function of the heritage building, not allowing the exclusion of elements on the expense of other elements under claims of unity of style or claims of returning to the original form [6].

The second International Congress of Architects and Technicians of Historic Monuments, Venice, 1964 is the resolution of continuous efforts and it establishes the basic principles of the analytical method of restoration. It stressed that the restoration should stop when the guesswork begins and that any new elements of utmost necessity must be linked to the heritage composition and bear the mark of its time. Marks of different ages have to be preserved-again- it is not the unity of style that is the purpose of restoration. Any reconstructed parts have to go with the heritage but yet it can be distinguished from original work to avoid falsifying the historic and artistic appearance of the heritage building [7].

\subsubsection{Architectural trends in dealing with heritage buildings}

There are various architectural trends to deal with heritage buildings. These trends vary in the methods and concept of dealing with heritage buildings. Some of the most prominent trends include [8]; 


\section{SJFA}

- Restoration while hiding added parts, in this process restoration takes place by using elements similar to the old elements so that it is difficult for the average viewer to distinguish between the old elements of the building.

- Restoration while revealing the added parts. This depends on making old parts and new parts distinguishable from one another.

- Revitalization and reuse that trend defers from other trends in that it is more of rebuild process than a traditional restoration and preservation project, where entire parts of buildings and neighborhoods are rebuilt using new materials and modern technologies and old dilapidated buildings are intended to be restored in modern architecture to deliberately show the contrast between modern and old. This trend is faced with the large opposition it is- for some-considered a mutilation and deformation of heritage buildings. But it is on the other side the representation of architectural thought that tends to show the strength and uniqueness of what is old to what is new. It tells the history through showing the development of nations with time.

\subsection{Green Buildings Definitions:}

\subsubsection{U.S. Environmental Protection Agency (EPA)}

Defines green buildings as structures that are made through processes that are accountable to the environment and that use resources effectively during the entire lifecycle of the building [9]. That notion extends beyond classical considerations of buildings like being economic, durability and comfortable. Green building is a term synonymous with sustainable buildings and high-performance buildings.

\subsubsection{U.S. Green Building council definition [10]:}

The buildings that are presumed to reduce negative impacts on individual's health and to the environment through:

- Effective utilization of energy, water, land, and other resources.

- Keeping the inhabitants safe and healthy while creating a productive environment for employees.

- Lowering levels of wastes and pollutants

- The continuous improvement of performance.

\subsubsection{Egyptian Green Building Council:}

This council is an affiliation of The Housing and Building National Research Center, the Egyptian Ministry of Housing, Utilities and Urban Development. It deals with green buildings as buildings that lower pollution levels and increase the effectiveness of energy and water utilization and that are designed for the purpose of reducing negative influences of inhabitants`activities to the health and environment. This includes the use of renewable sources of energy and application of recycling and reducing pollution approaches. It also takes into account the sustainability of land, water, energy and all other resources [11]. That, in turn, would be expected to reflect itself in the improved environment and economy of inhabitants.

\subsection{Environmental Rating systems around the world:}

Since the year 1990, a large number of environmental rating and evaluation systems as shown in Pic. (1) Had emerged. It included, Building Research Establishment Environmental Assessment Method (BREEM), High Quality Environmental standard - HQE, Leadership in Energy \& Environmental Design LEED, Leadership in Energy \& Environmental Design LEED CANADA, Green Star Rating System, Green Mark, Rating System Program (Estidama), Green Building Index GBI, and Green Pyramid Rating System GPRS. They all had one thing in common, it is that they all don 't have the sensitivity to deal with the exceptional nature of heritage buildings. According to these rating systems, heritage building is rated IP a g e $\mathbf{2 5}$ 
like any other existing building and that is according to a classification merely dependent on the function of building such as; Residential buildings, office buildings, educational buildings, health buildings, markets, hotels, prayer places, courts, prisons, factories, urban communities or infrastructure, regardless to the nature of the heritage building. This can result in problems when a heritage building is to be converted into a green building that has to use energy and resources effectively, preserve water, adapt to the climate, and reduce wastes and emissions. And had respected internal, external environment of the building and its location and users.

Pic (1): Map shows different rating systems around the world.

\section{RESEARCH AIM}

This research aims incorporate green architecture principles into the process of restoration of a case study building of heritage significance.

\section{MATERIAL AND METHODS}

The research first studies an international model of transforming a heritage building into a green building (Christman Building). In the case study the research presents an important heritage building (Mansoura Opera House), and tests the possibility of restoring and transforming it into green building, Sefaira web application (ASHRAE 90.1.2013) [12], is used to compare the properties of current building and number of virtual scenarios use minimal energy through daylight visualization. Autodesk insight 360 [13] is used to show the significance of using solar energy

\section{DISCUSSION}

Sustainability of heritage buildings can be defined as a process of developing a heritage building while considering its heritage value and elements that define its characters, together with applying sustainability practices. There is a large number of studies that dealt with heritage buildings in order to transform them into green buildings, but these studies didn`t deal with the building as a heritage building but as an existing building. Of course, when it comes to restoration and rebuilding processes that would require a different intervention according to the charter of Venice.

\subsection{Examples of heritage buildings transformed into green buildings:}

LEED is one of the environmental rating systems and there is a number of historic preservation projects that are LEED-EB, these buildings are preserved and are green sustainable buildings at the same time including:

- Fay House at Harvard University, United States, 1807 (the oldest LEED building in the United States) 


\section{SJFA}

- Gothic Palazzo in Venice, 1453 (oldest LEED building in the world)

- Empire States Building

- Chrysler Building,

- Merchandise Mart, Chicago.

- Colorado State Capitol Building.

- Christman Building (Central Business District, Lansing, Michigan), 1928.

One of which will be mentioned with some details.

\subsubsection{Christman Building:}

This building received platinum Certification, it achieved a number of requirements including; innovation, sustainable site and effective water, energy, atmosphere, and resources utilization all that

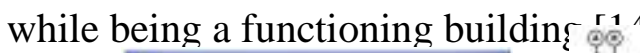

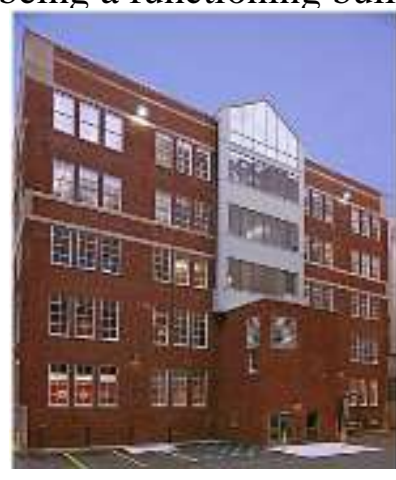

A: In 1928

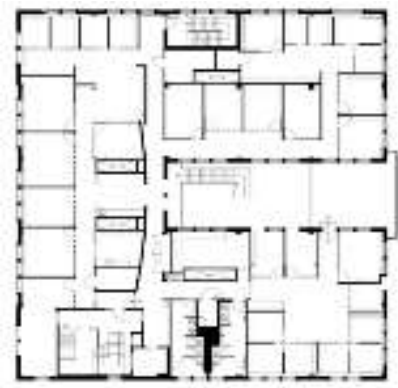

D: Fifth floor plan

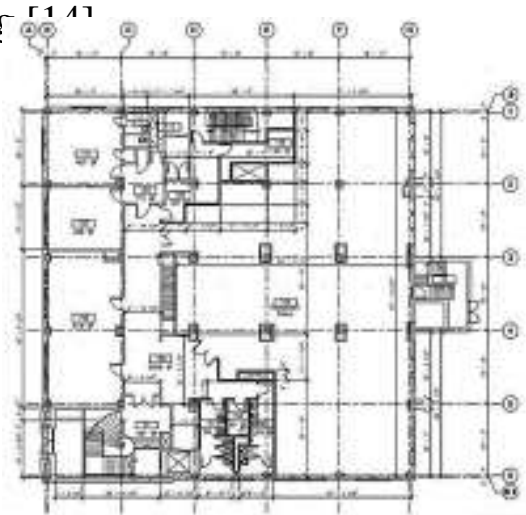

B: Ground floor plan

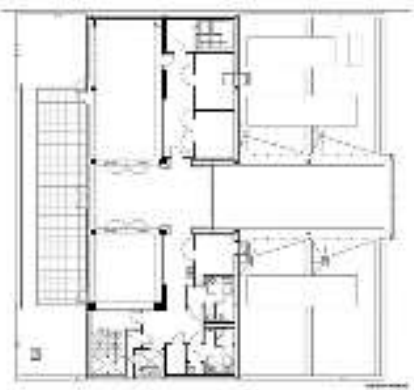

E: Sixth floor plan

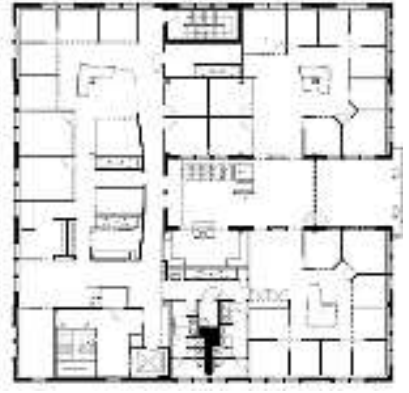

C: Fourth floor plan

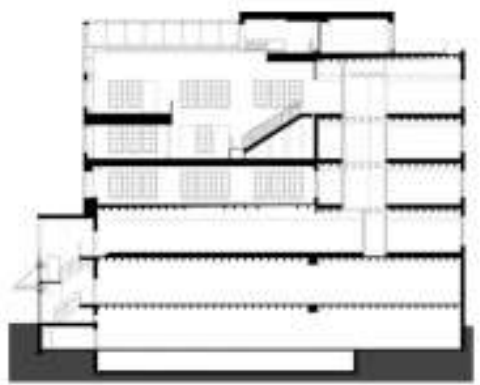

F: Cross section

Pic. (2): Christman Building

\subsubsection{Description:}

The six-story Administrative building as shown in Pic. (2), A, B, C, D, E, F, with Elizabethanrevival style and brick and limestone cladding front as shown in Pic. (2A), the entrance at the southwestern corner was restored and had the blue stoned floor and multi-colored wall. The restoration process intended to show the contrast between old and new where other materials were used like glass and wood for the doors on the first floor.

\subsubsection{Historical Background:}

It was:

- Used as the main office for Michigan Millar insurance company (1928-1950).

- Used as offices of Michigan state (1950-2003). 
- Purchased by Christman Company and left vacant (2006).

The evaluation of overall performance of the building shows that the building operates generally in a green sustainable way and that is revealed in a number of points [14]:

- In order to improve the environmental performance of location and decrease use of fuel emission from transportation to and out of the building, as shown in Pic. (2A), there are a number of bus lines to the area to serve as substitutes to personal transportations. Boosting use of bikes by providing bike racks. Lockers and showers were provided to help individuals to walk or run to work. Parking lots were provided to be reserved preferably by fuel competent personal transportations.

- For sustainability consideration, the old millstones of the building`s sidewalk were removed sensibly and applied to the front façade, as shown in Pic. (4).

- A white roof was installed to reduce heating and light pollution was minimized by using solar power LED systems.

- Energy effective systems that include; occupancy sensors, energy star rated computers and refrigerators, use displacement ventilation, water heating system was energy efficient by $20 \%$, low ceiling height and downward directed light as shown in Pic. (5).

- Using materials and resources that are eco-friendly where refrigerators and coolers used minimal ozone depleting systems, use biodegradable materials and encourage recycling by having a coordinator of recycling and designing in-house recycling system that includes labeling the bins, use only low mercury emission lamps as shown in Pic. (6).

- The indoor environmental quality aimed to lower toxic wastes and controlling pressure, humidity and most of all a continuous process of evaluation that ensures that the aims of the design are achieved as shown in Pic. (7, 8).

- The facility was altered in the most innovative way to meet the requirements of efficient water and energy use.

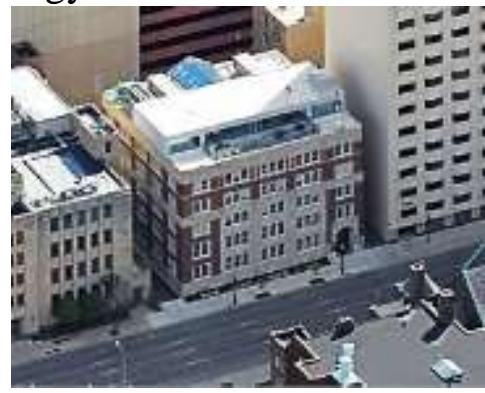

Pic. (3): Building Location

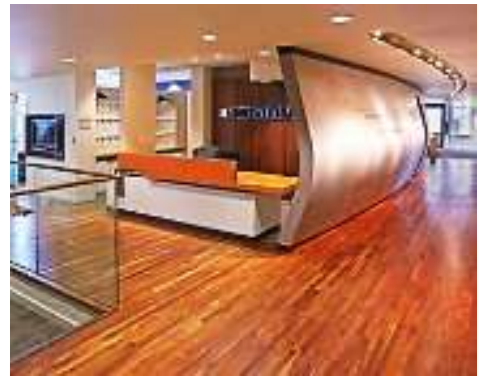

Pic. (6): Finishing's materials

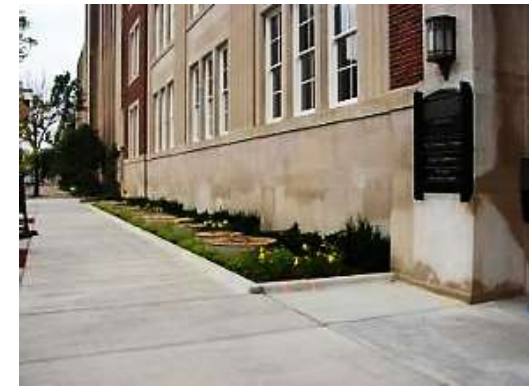

Pic. (4) Sustainable sites

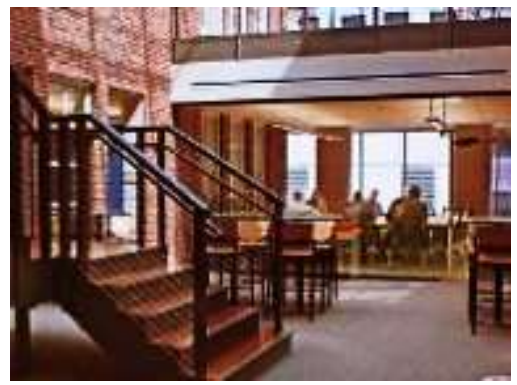

Pic. (7): Indoor environmental quality

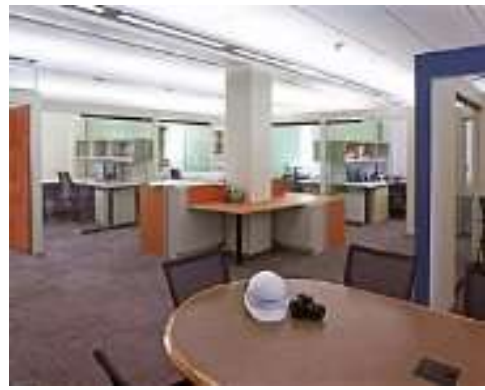

Pic. (5): Energy and internal atmosphere

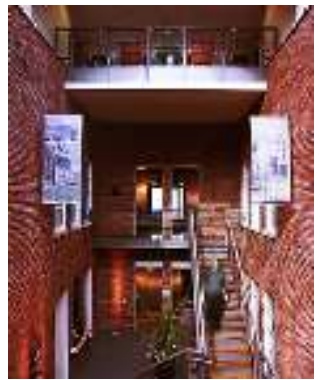

Pic. (8): Sixth-floor addition overlooks the Christman building's atrium space

\subsection{Case study: Municipal Council (Mansoura Opera House):}

\subsubsection{Historical Background:}




\section{SJFA}

There are two stories told about the history of the building: the first one indicates that the building is the first and oldest theater in Mansoura city. It was opened on the $18^{\text {th }}$ of December, 1889 , and was called "Al-Tafreeh Teatro" which means Joy theatre for more than thirty years (1889-1920). As shown in Pic. (9), when it changed its name to Municipal Council theatre [17] as shown in Pic. (10). the second story indicated that it was the municipal council and was built in 1902. It was owned by Khawaja Leon Kun and his partner and was designed by the Italian architect A. Marelli [16] in neo-classical style. According to archives in 1918-1933 it was a mixed-use building including; the Municipal Council Casino, Billiard Hall, and Municipal Council Chamber. The building consists of many rooms, and a municipal council members meeting hall. In 1934, the theatre was renovated. And in 1942, a fire extinguishing carts hall was added and then removed. The validity of these two stories is well known, as it is a national heritage building in Mansoura city. Like Christman building it served as office building where its last function was Mansoura Municipal Council, Mansoura National Theater, and the United Bank Main Branch.

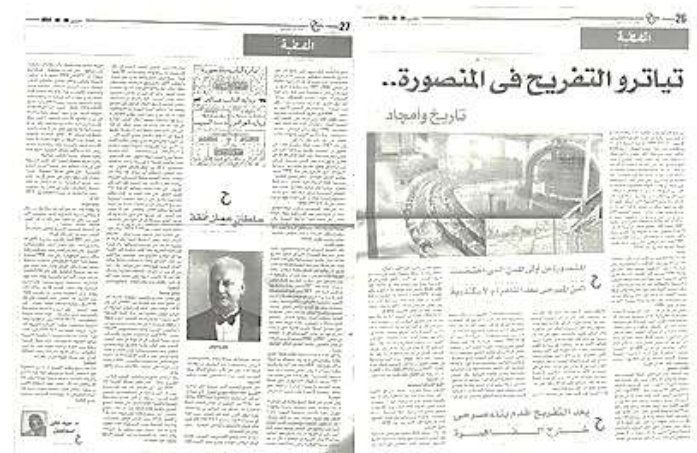

Pic. (9): Headlines of the newspaper (AlMoayed) on December 18, 1889 under the name "Al-Tafreeh teatro"- Joy theatre

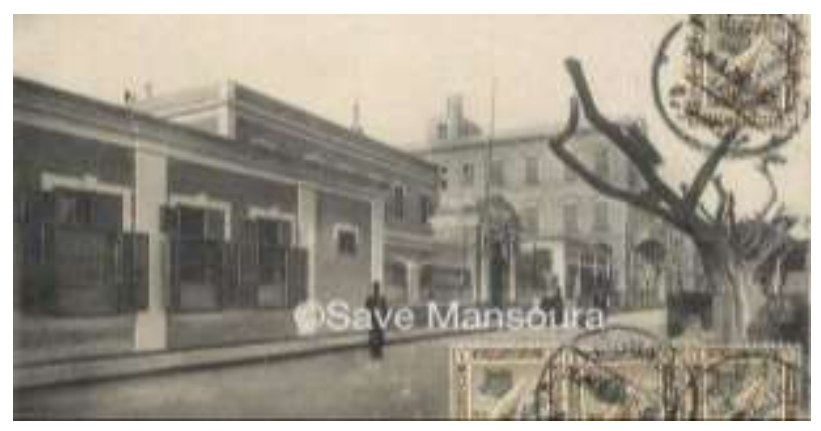

Pic (10): A picture dating back to 1922. Shows Mansoura National Theater next to the police station, which is known nowadays as Al-Dakahlia Security

\subsubsection{Building Description [15]:}

It is a cuboid building with a rectangular floor plan shows four free facades, consisting of three floors as shown in Pic. $(11,12,13,14,15,16)$. Mass composition, the design of facades and pattern of void reveals its neo-classic style.

The main façade of the building is the northern façade as shown in Pic. (19, 20) it is symmetrical around a vertical axis at the center of the facade. It is characterized by continuous balconies that occupy more than half the width of the façade in typical floors. The main façade is in Neo-classic style. There is one model of balconies in the center of the façade in typical floors they are rectangular protruding balconies carried by four classical gypsum cantilevers, with brick wall and gypsum decorative stands. The openings in the façade are rectangular with classical proportions and that in all typical floors. The ground floor was modified by the Bank. The façade in the ground floor is made up of five openings of similar shape with large Pre-modern arches, four of these openings for glass-curtain windows, and on the left of the façade is the opening of bank entrance. At the center of the façade in the first and second floor prominent balcony with Neo-Classic handrail of Gypsum decorative stands. Each balcony has three openings for doors with mesh mat. On each side of the balcony on the first and second floor, there is a rectangular window with mesh mat and handrail of Gypsum decorative stands from the bottom. The openings in first floor facades are topped by gypsum triangular arches with a neo-classic cantilever on both sides. The openings of the second floor are topped by rectangular Gypsum cornice with classical floral motifs topped by a prominent roof finally topped by the rooftop of the buildings. The façade ends with an upper classical terminus in the center of the façade below the rooftop. 
M. M. Abou Leila, M. W. Madkour, Restoration Towards Sustainable Green Heritage Buildings, Case Study: Mansoura Opera House, Mansoura, Egypt;Vol. 6, R. 2018, Issue No. 1.

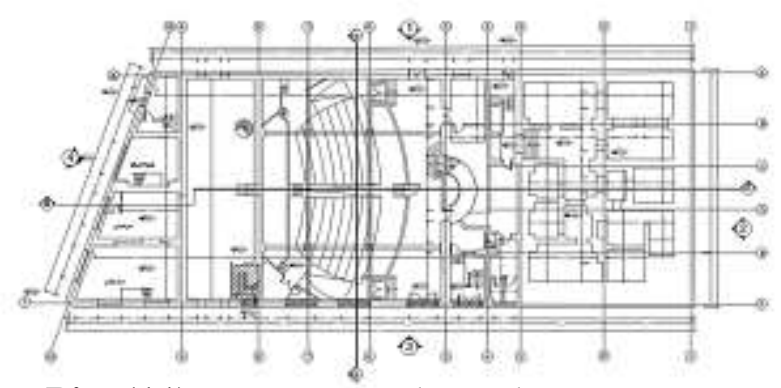

Pic. (11): Basement Floor plan

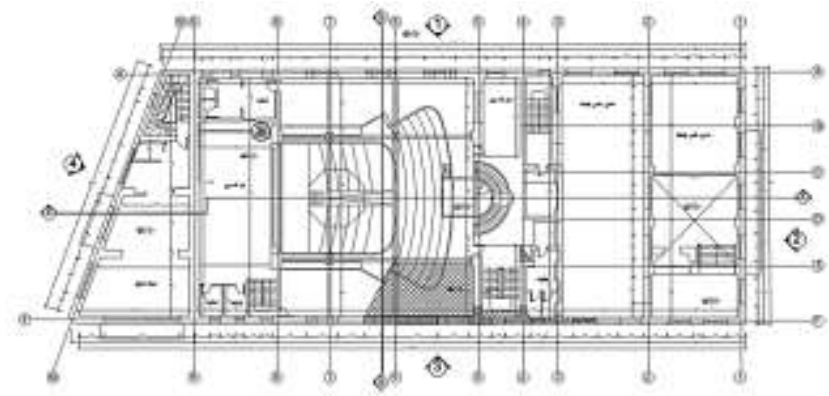

Pic. (13): Mezzanine Floor Plan

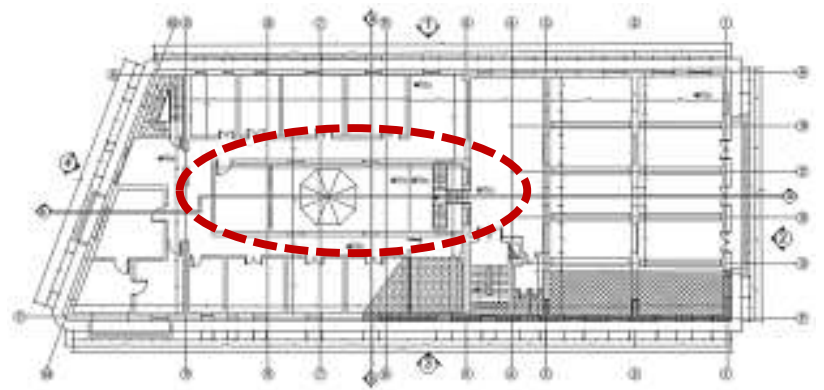

Pic. (15): Second Floor Plan

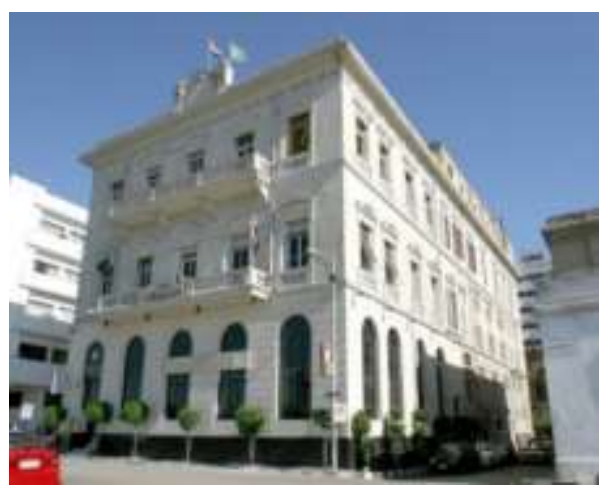

Pic (17): Main and eastern façade in 2004.

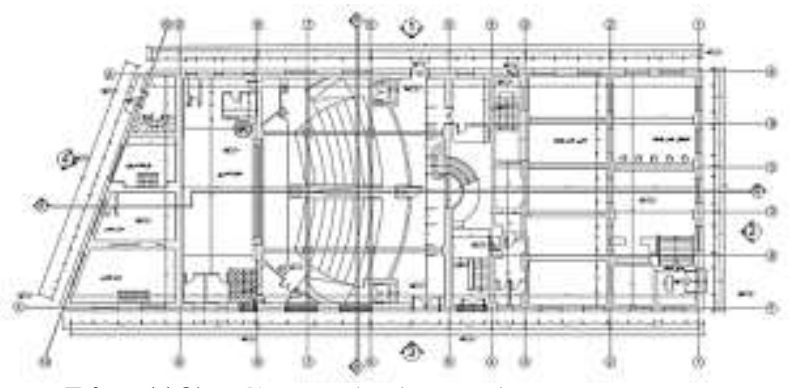

Pic. (12): Ground Floor plan

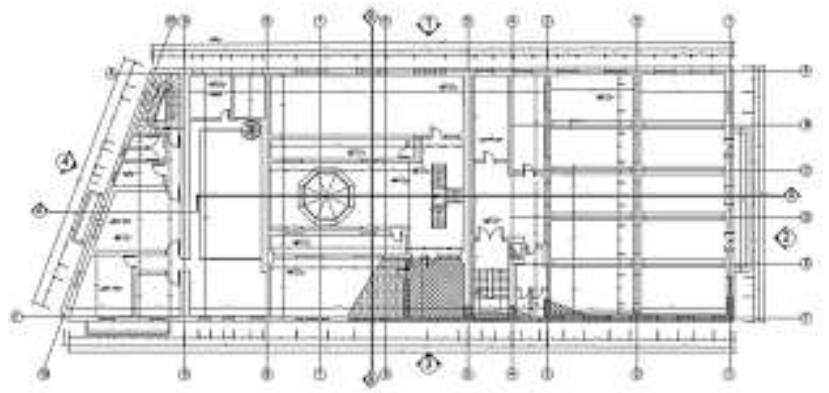

Pic. (14): First Floor Plan

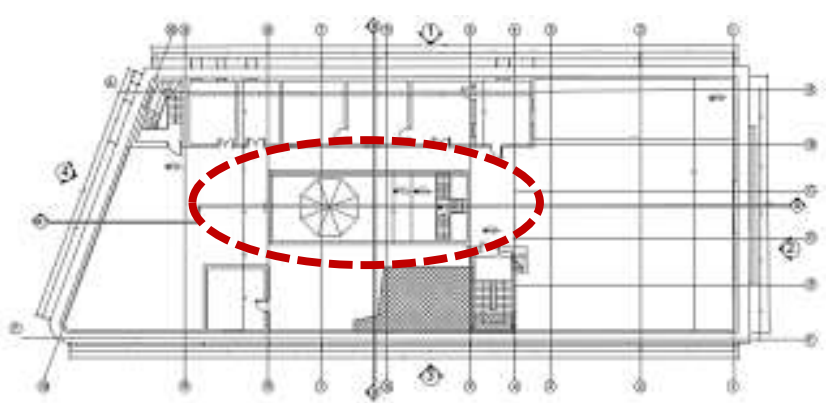

Pic. (16): Last Floor Plan

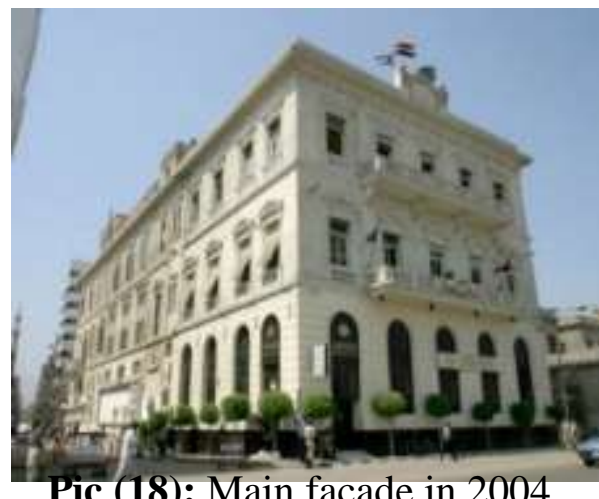

Pic (18): Main façade in 2004.
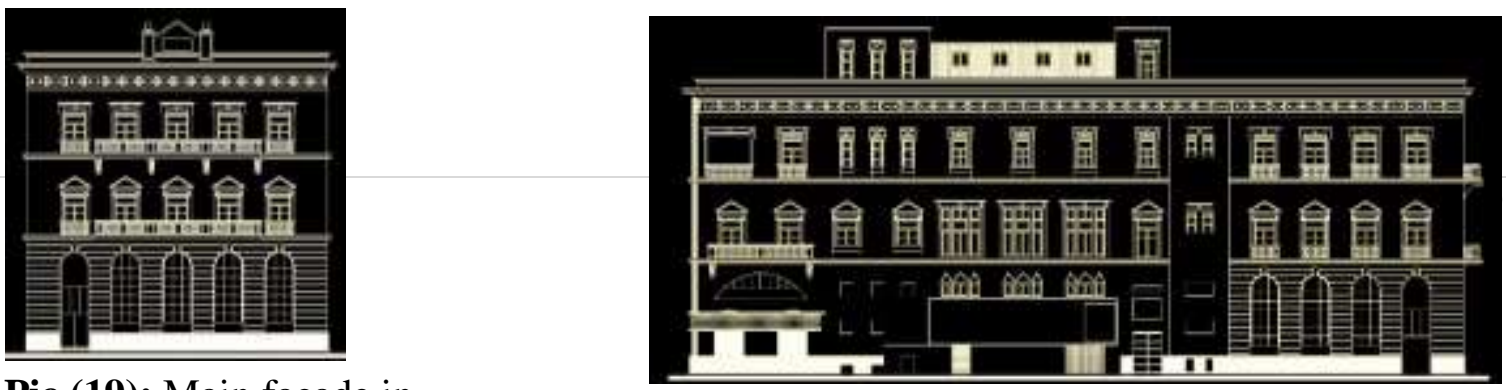


\subsubsection{Mansoura Opera House after Destruction}

On the $24^{\text {th }}$ of December, 2013, night a terrorist explosion occurred in Al-Dakahlia Security Directorate adjacent to Mansoura opera house building, in which 11 people were killed and about 100 others were injured. The building was destroyed as shown in the following Pictures $\mathbf{( 2 1 , 2 2 , 2 3 , 2 4}$, and 25). The renovation works of the opera house were carried out by national companies and work is still in progress as shown in Pic. (26,27). The repairs and rebuild carried out by Arab contractor's company and was based on studies that relied on restoration only and not take in account the fact that the building is a historical building registered on the lists of National Authority for Civilizational Coordination as a heritage building in the province of Dakahlia.

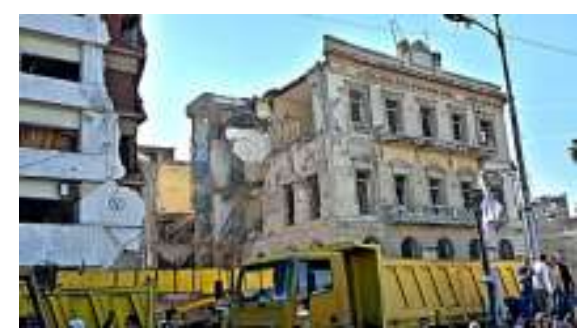

Pic (21): The main and eastern Façade with the entrance of the opera house was destroyed in

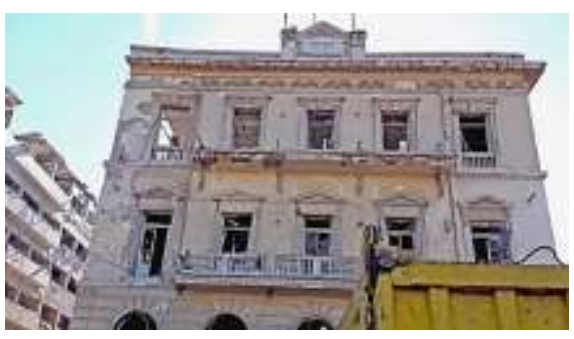

Pic (22): The fully destroyed front Façade in 2014

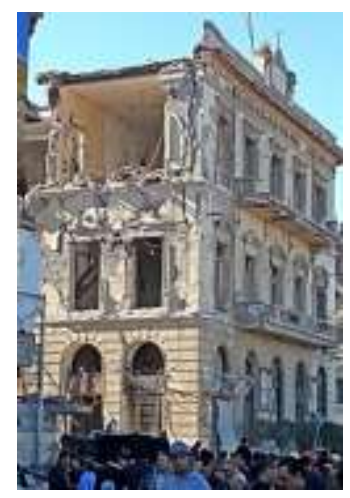

Pic (23): Building destruction in 2014

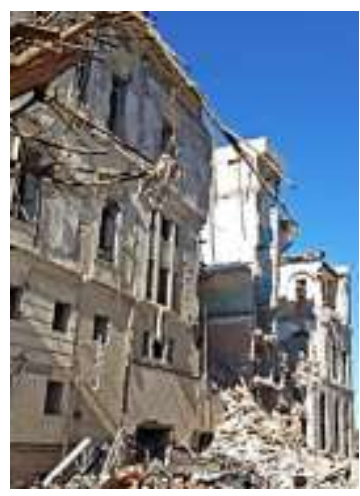

Pic (24): Remains of eastern facade in 2014

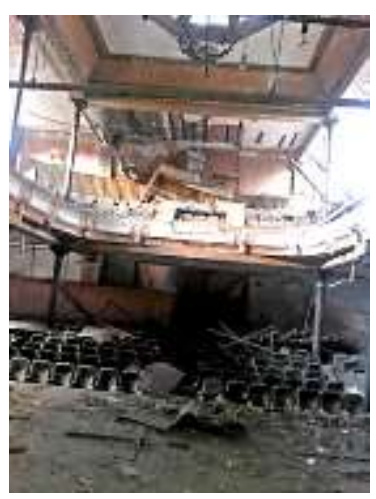

Pic (25): The opera atrium after destruction in 2014

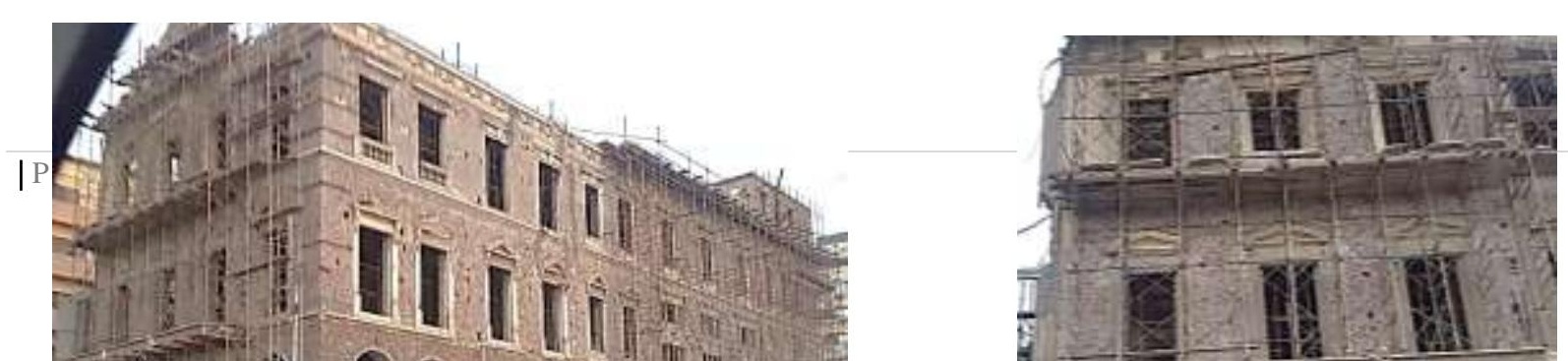




\subsubsection{Greening the Mansoura Opera House after Restoration \& Reconstruction: different scenarios}

\subsubsection{Increasing the amount of natural daylighting:}

Based on the preliminary studies held by the contracted company and with the application of Sefaira software researchers [18] suggest two scenarios for the restoration and reconstruction as a way for greening the building by focusing on minimizing energy utilization through daylight visualization. One of these scenarios could be applied after restoring and reconstructing the building. First Scenario: expanding the inner courtyard in the last two floors to increase natural lighting through a number of recommendations as shown in Pic. $(\mathbf{2 8}, \mathbf{2 9})$.

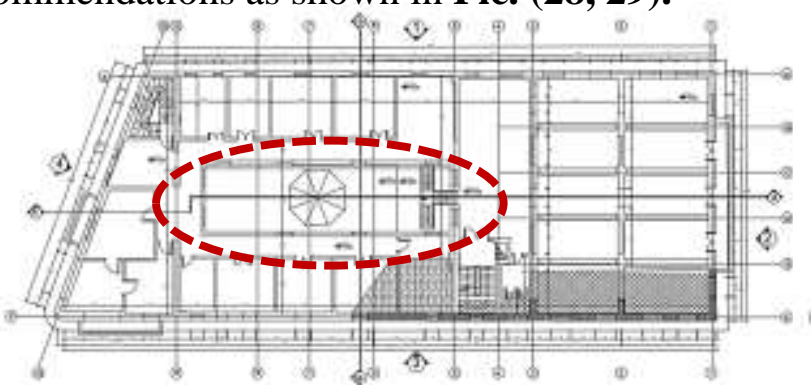

Pic. (28): First Scenario: increasing natural daylighting by expanding the inner courtyard in the second Floor plan

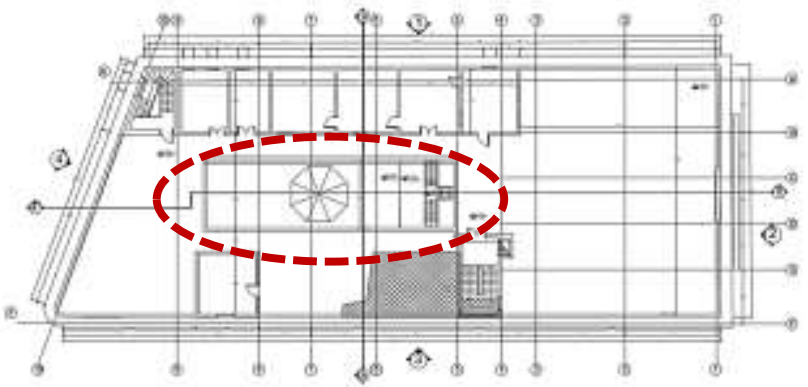

Pic. (29): First Scenario: increasing natural daylighting by expanding the inner courtyard in the last Floor plan

Second scenario: expanding the inner courtyard and adding a new courtyard to the last two floors of the building to increase natural lighting through a number of recommendations as shown in Pic. (30, 31).

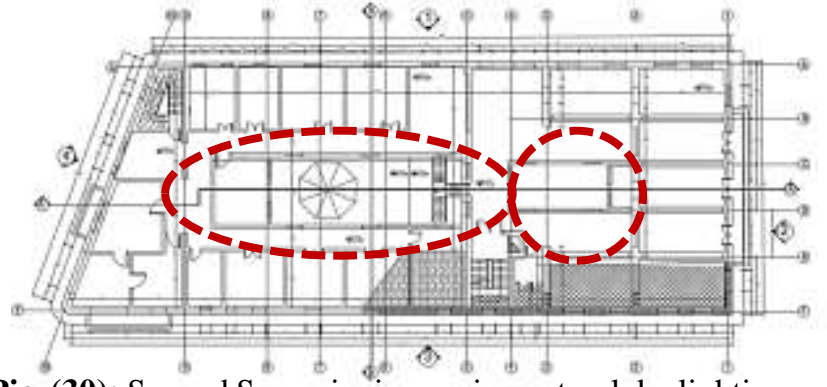

Pic. (30): Second Scenario: increasing natural daylighting by expanding the inner courtyard and adding a new courtyard to the last two floors of the building

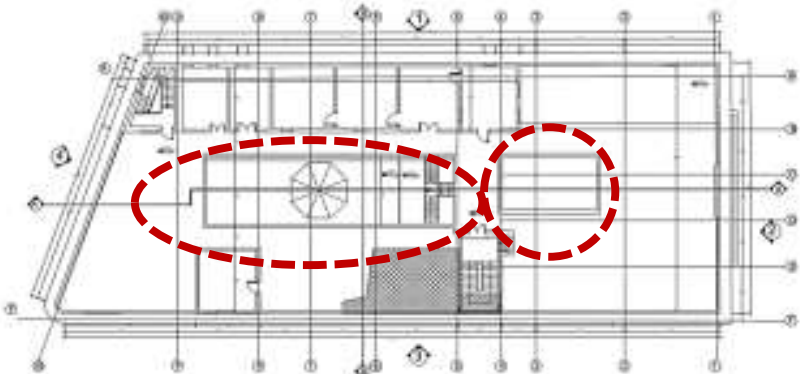

Pic. (31): Second scenario: increasing natural daylighting by expanding the inner courtyard and adding a new courtyard to the last floor of the building

Table (1) shows a comparison between the current situation of the building and the two postulated scenarios according to daylighting visualization. 
Table (1): comparison between the current situation and the two postulated scenario according to daylighting visualization

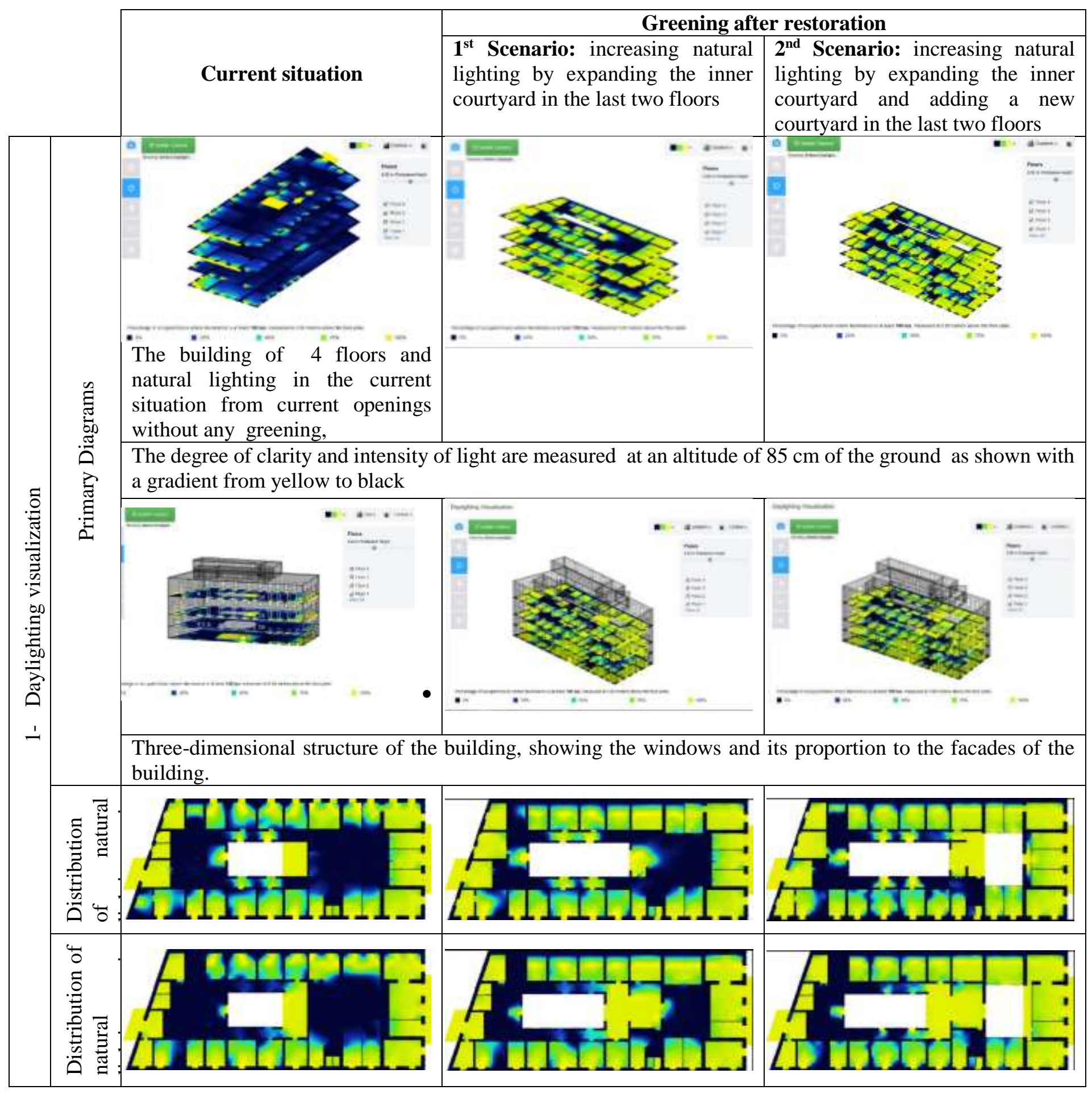




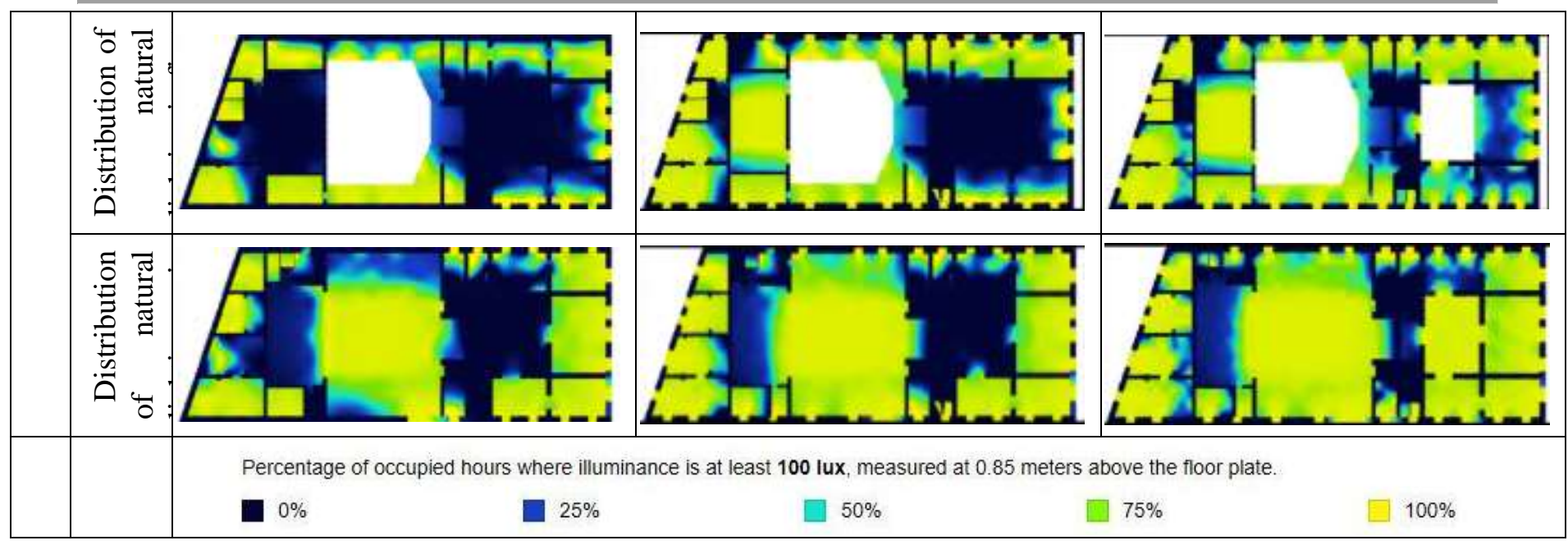

\subsubsection{Decreasing the amount of electrical energy:}

Researchers used Autodesk insight 360 [19] to show the significance of using solar energy through comparing current situation of the building with the situation after application of photo-voltaic cells PV on its rooftop as shown in Pic. 32, 33, in terms of Energy consumption, Impact on Heating Hours, Impact on Cooling Hours and Equipment as shown in Table (2). Daylight visualization together with the use of sustainable energy source would be expected to improve the overall energy for the building performance.

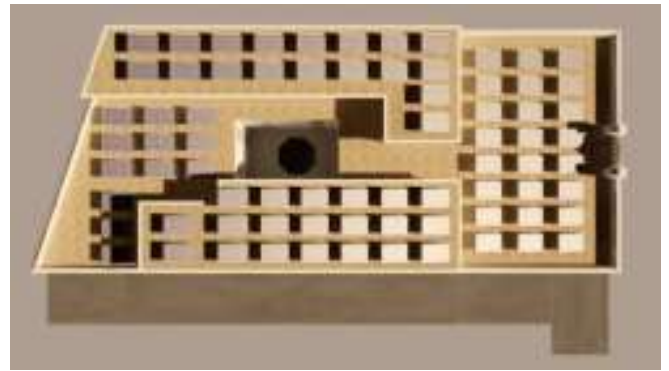

Pic. (32): lay out shows the photovoltaic cells

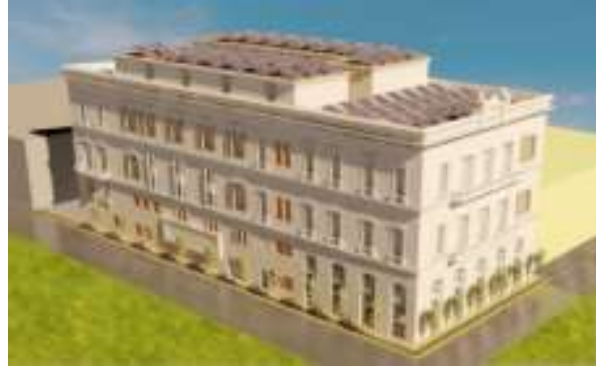

Pic. (33): virtual visualization of the green Municipal Council after using photovoltaic cells on the ceiling of the building

Table (2): Comparison of the Current Situation and the situation after restoration and greening 


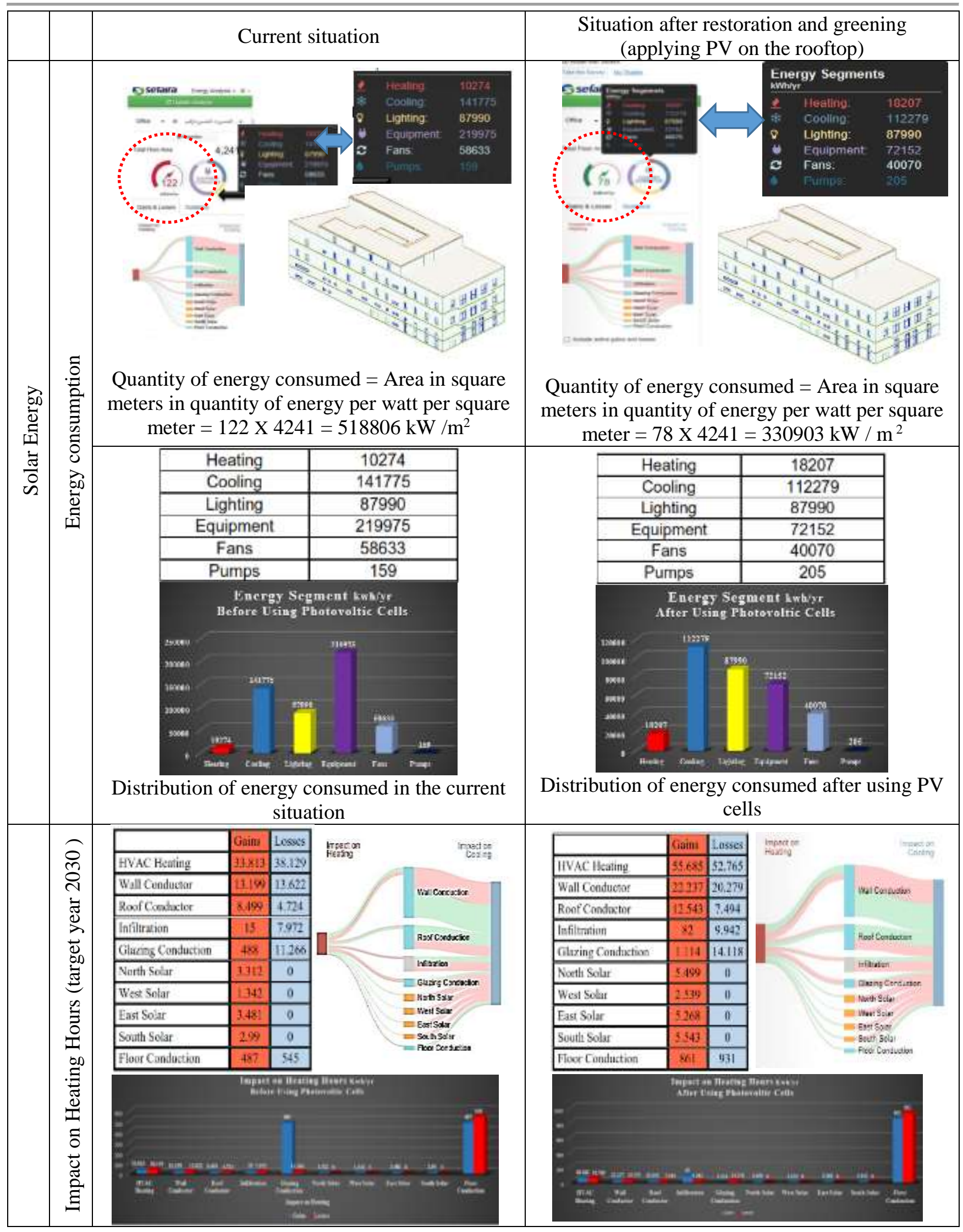


M. M. Abou Leila, M. W. Madkour, Restoration Towards Sustainable Green Heritage Buildings, Case Study: Mansoura Opera House, Mansoura, Egypt;Vol. 6, R. 2018, Issue No. 1.

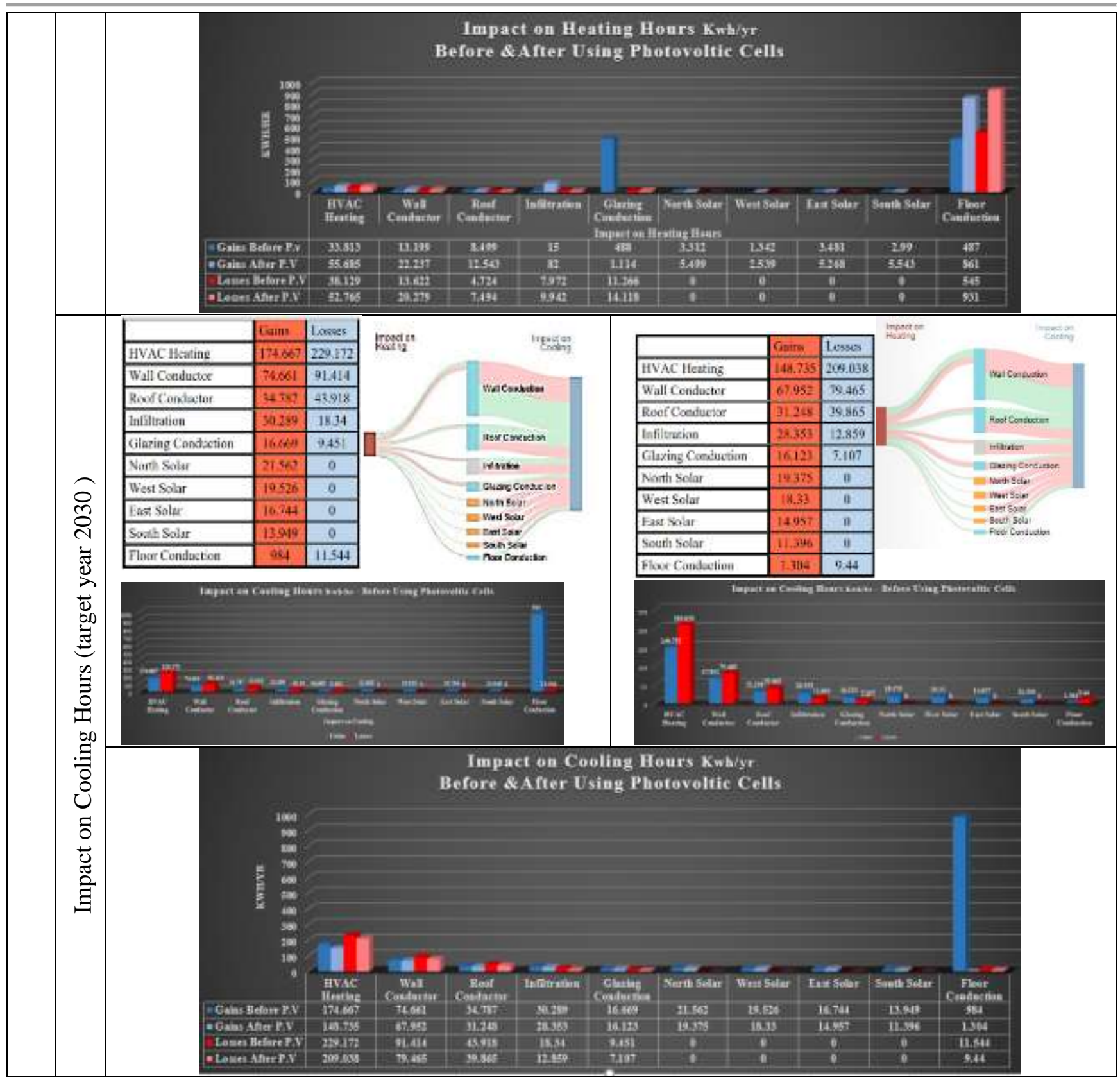




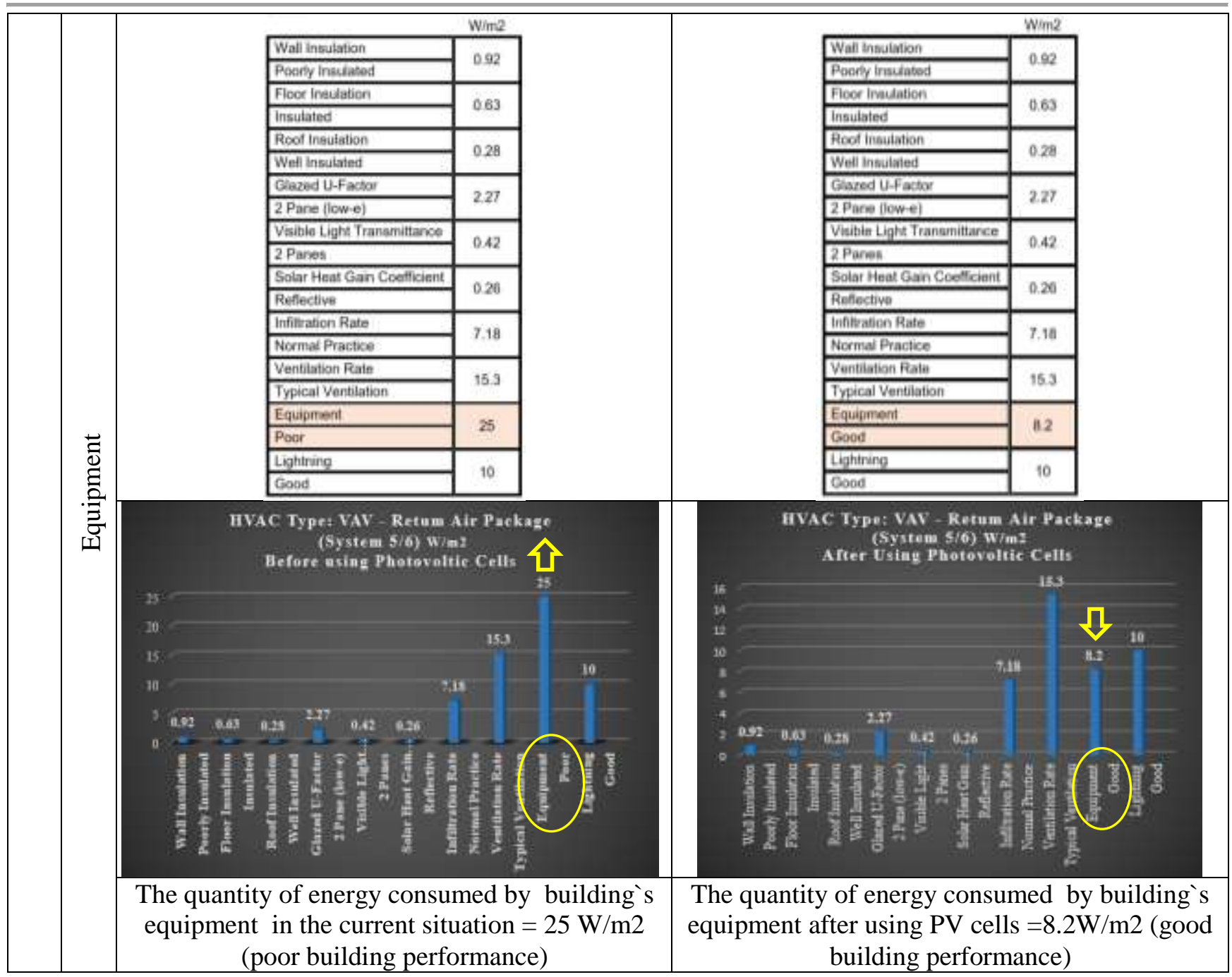

\section{RESULTS AND CONCLUSIONS:}

- Concerning daylight visualization, the second scenario is set to be the best choice as it where it achieves the best utilization of daylight compared to the current situation and the first scenario thus will reflect itself in energy conservation.

- Analyzing data collected from Autodesk insight 360 revealed that PV cells installation on the rooftop of the building will save a total of $186604 \mathrm{~kW} / \mathrm{m}^{2}$ per year.

\section{RECOMMENDATIONS:}

Based on the previous case study there are numbers of recommendation for restoration and greening of the building under study, as follow:

\subsection{Restoration recommendations:}

- It is preferable to use the original stones of the destroyed building in the new building- in accordance with the principles and criteria for assembling the original elements in the projects Reconstruction- after cleaning and testing against pressure impact. To make these remains a distinctive feature of the new building. 
- $3 \mathrm{D}$ graphics programs can be used to determine the appropriate places for the use of ancient stones with their unique appearance and color- these stones are more than 120 years old- will be distinguishable compared to modern sandstone of the new building. The contradiction between the original and new blocks will be in line with the Venice Charter.

\subsection{Greening Recommendations:}

There is a number of recommendations that can be very handy if applied to the restored building to improve its overall performance and transform it into a greener version and that include:

\subsubsection{Increasing the amount of natural daylighting recommendations:}

- Application of occupancy sensors to automatically turn lights on and off together with light sensors that accommodate the amount of daylight in the space to achieve a balance between illumination and energy conservation.

- The optimum combination of light fixtures and lamps will help deliver the required amount of light while consuming least amount of electricity and generate the least amount of heat

\subsubsection{Decreasing the number of electrical energy recommendations:}

- Reducing cooling and heating loads will require minimizing solar heat gain and allowing naturally occurring air current to cool indoor spaces.

- Appling climate -based building façade or climate responsive façade through a number of strategies including; double glazing, shading of walls, insulation or envelopes, a reflection of Daylight and allowing natural ventilation.

- Heat insulation envelops will reduce the reliability of mechanical cooling and heating equipment. The good envelope doesn't mean more insulation it`s a function of infiltration rate which means control of air leakage into and out of the building lower infiltration rate would mean good regulation of temperature and lowering energy utilization for heating and cooling equipment.

\section{REFERENCES:}

1. INTERNATIONAL CULTURAL TOURISM CHARTER Managing Tourism at Places of Heritage Significance (1999) Adopted by ICOMOS at the 12th General Assembly in Mexico, October 1999, [cited 2018, Feb.9] https://www.icomos.org/charters/tourism_e.pdf,

2. INTERNATIONAL CULTURAL TOURISM CHARTER (Managing Tourism at Places of Heritage Significance, 1999) Adopted by ICOMOS at the 12th General Assembly in Mexico, October 1999, [cited 2018, Feb.9] https://www.icomos.org/en/about-icomos/image-menu-about-icomos/179-articles-en-francais/ressources/chartersand-standards/162-international-cultural-tourism-charter.

3. Convention for the Protection of Cultural Property in the Event of Armed Conflict with Regulations for the Execution of the Convention 1954, (14 May 1954), [cited 2018, Feb.3] http://portal.unesco.org/en/ev.phpURL ID=13637\&URL DO=DO TOPIC\&URL SECTION=201.html .

4. International Charter for the Conservation and Restoration of Monuments and Sites (THE VENICE CHARTER 1964) [cited 2018, Feb.5] http://www.icomos.org/charters/venice_e.pdf,.

5. Ghaleb, A. \& Abdullah M., Directory of preparation of projects for the maintenance and restoration of monuments, Journal of Egyptian Antiquities Authority- Egyptian Ministry of Culture. (1992).

6. Massimo C. and Conlynn G., (2006), English translation of Italian Restoration Chart of 1972, [cited 2018, Feb.18] http://sangem.s3.amazonaws.com/wp-content/uploads/2015/11/Italian-Restoration-Chart-of-72-rev-08.pdf,.

7. INTERNATIONAL CHARTER FOR THE CONSERVATION AND RESTORATION OF MONUMENTS AND SITES (THE VENICE CHARTER 1964) $2^{\text {nd }}$ International Congress of Architects and Technicians of Historic Monuments, Venice, 1964. Adopted by ICOMOS in 1965, [cited 2018, Feb.17] https://www.icomos.org/charters/venice_e.pdf,.

8. Bassam M., The Role of Reconstruction in the Preservation of Monuments and Historic Sites, Journal of the General Union of Arab Archaeologists - General Union of Arab Archaeologists in cooperation with the Arab Council for 
Higher Studies and Scientific Research of the Union of Arab Universities and the Supreme Council of Antiquities. ISBN 12864/2010 (January 2009).

9. U.S. Environmental Protection Agency, [cited 2018, Feb.17] http://www.epa.gov/greenbuilding/pubs/about.htm,

10. Green Building Education Service (September 2010), "LEED Green Associate- Study Guide", Lewisville, USA, page 3.

11. The Egyptian Green Building Council (April 2011), "The Green Pyramid Rating System", First Revision: following Draft document dated May 2010, For Public review, The Housing and Building National Research Center, Ministry of Housing, Utilities and Urban Development, Egypt. Page 5.

12. Sefaira Support, [cited 2018, Jan.26] https://sefaira.zendesk.com/hc/en-us?mobile site=true.

13. Autodesk Insight 360, [cited 2018, Jan.26] https://insight.autodesk.com/oneenergy,.

14. U.S. Green Building Council USGBC and GBCI staff. (2013). Leadership in energy, and environmental design (LEED), Reference guide for building operation, and maintains. Washington, DC.

15. "Al-Tafreeh" "- Joy theatre in Teatro Mansoura.. History and glories, [cited 2018, Feb.18] http://kenanaonline.com/users/sayed-esmail/posts/628060,.

16. Al-Kerdani, D., et.al (2005), International Heritage of Mansoura City: Fact or Illusion? International Seminar on the Management of the Shared Mediterranean Heritage (ISMARMED), 29-31 Mar 2005, Bibliotheca Alexandrina.

17. The first Author Abou Liela, M., was one of the Mansoura urban and architectural heritage documentation team, a project financed by CENTER FOR DOCUMENTATION OF CULTURAL AND NATURAL HERITAGE (CULTNAT) started in 2003 and finished in 2004, [cited 2018, Feb.18] http://www.cultnat.org/ProjectDetails/58/Architectural_Heritage_-_Zamalek_amp;_Mansoura ,

18. Sefaira Support, Additional Useful Information, [cited 2018, Feb.26] https://sefaira.zendesk.com/hc/enus/articles/210495843-Managing-Internal-Loads-Efficient-Equipment?mobile_site=true,.

19. Discover Insight 360 for Building Energy Modeling, [cited 2018, Feb.26] https://medium.com/autodeskuniversity/discover-insight-360-for-building-energy-modeling-272e13a7bb0 . 


\title{
SJFA
}

الاورية العلمية لكلية الفنون الجميلة - جامعة الإسكندرية

Scientific Journal of the Faculty of Fine Arts Alexandria University

\section{إحياء المباني التراثية: نحو مباني تراثية خضراء مستدامة

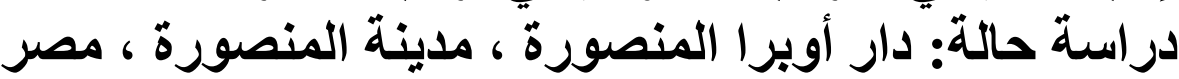

\author{
د.محمد محمد شوقي عبد العليم أبوليله 3 \\ د. مي و هبة محمد حسن مدكور 4
}

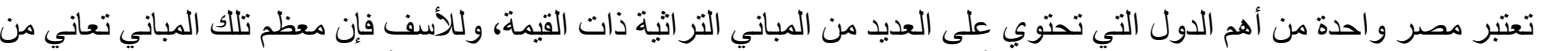

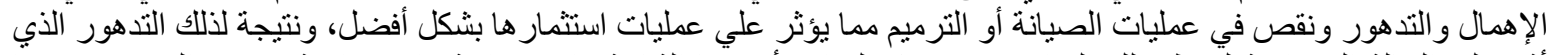

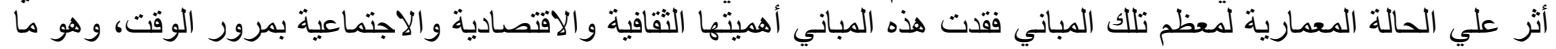

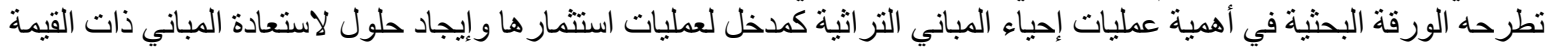

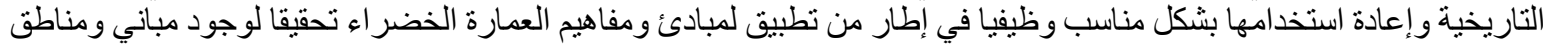
تر اثثة خضر اء ومستدامة.

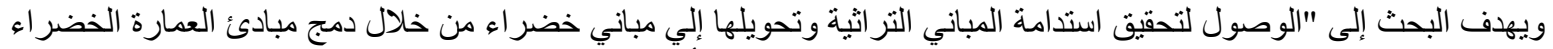

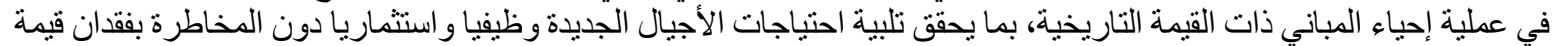
المباني التراثية".

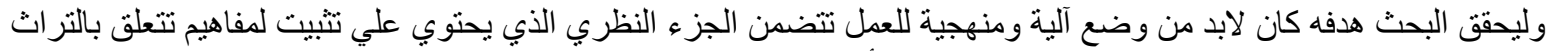

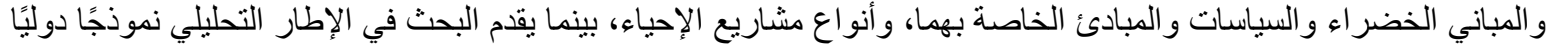

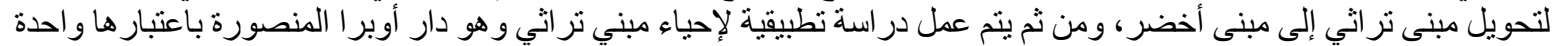

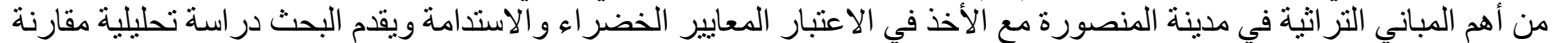

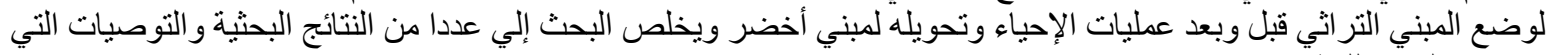

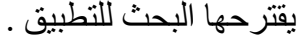

الكلمات الدالة : الإحياء ، المباني التتراثية ، الحفاظ ، التراث الأخضر ، الاستدامة ، دار أوبرا الدنصورة

3 استاذ مساعد بقسم الهندسة المعمارية جامعة المنصورة

m_shawky_lila@yahoo.com mmshlila@mans.edu.eg

4 مدرس العمارة قسم الهندسة المعمارية جامعة طنطا maimadkour@yahoo.com mai_madkour@f-eng.tanta.edu.eg 